ERRATUM

doi:10.1038/nature14303

\title{
Erratum: A new antibiotic kills pathogens without detectable resistance
}

Losee L. Ling, Tanja Schneider, Aaron J. Peoples,

Amy L. Spoering, Ina Engels, Brian P. Conlon, Anna Mueller,

Till F. Schäberle, Dallas E. Hughes, Slava Epstein, Michael Jones,

Linos Lazarides, Victoria A. Steadman, Douglas R. Cohen,

Cintia R. Felix, K. Ashley Fetterman, William P. Millett,

Anthony G. Nitti, Ashley M. Zullo, Chao Chen \& Kim Lewis

Nature 517, 455-459 (2015); doi:10.1038/nature14098

In Fig. $3 d$ of this Article, the ' $2: 1$ ' and ' $1: 1$ ' labels at the bottom of the panel were inadvertently switched during the production process; this figure has now been corrected in the online versions of the paper. 